\title{
Breaking the myth about rational investor: Investors' susceptibility to heuristical and biased reasoning
}

\author{
ANDRIJANA MUŠURA GABOR and LIDIJA GAMULIN
}

\begin{abstract}
The theory of rational investors has empirically proven not to be an accurate model for describing how investors in reality behave. However, there is a great number of finance theorists and orthodox economists that advocate the theory of homo economicus. In this paper, we take closer look at susceptibility of investors to heuristics and biases in general, and look at some individual differences with respect to committing to these biases. Individual differences include educational background, professional experience, and years of investing experience. We found that susceptiveness to heuristics and biases is present in majority of hypothetical scenarios. With regard to individual differences, we found that educational background can play a role in susceptiveness to heuristics and biases.
\end{abstract}

Key words: behavioral finance, heuristics, biases, investors' rationality

This study focuses on the question of rationality. Interest in decision making has been preoccupying researchers and public from many different fields and perspectives. Assumptions about consumer behavior shape companies' strategy and marketing activities, laws and public policies, bank products, etc. It affects the society as a whole. The discipline of economics largely contributed to defining (rational) preferences and choices of most (rational) individuals. The theory of rational choice has shaped classical, neoclassical, and mainstream economics in general. Although it has been widely contested, it had far-reaching effect in sociology, political science, philosophy, and even evolutionary theory (Browning, Halcli, \& Webster, 1999). Since the middle of the $20^{\text {th }}$ century, however, many premises about rational consumer have been shattered. The work of Simon (1955), Tversky and Kahneman (1974, 1981, 1983), and Kahneman and Tversky $(1979,1992)$ contributed to more real and descriptive understanding of how people really reason.

Recent economic crisis brought into light these rationalbehaving-people presumptions and gave more space to alternative explanations. One of them came from the field of

Andrijana Mušura Gabor, Zagreb School of Economics and Management, Jordanovac 110, 10000 Zagreb, Croatia. E-mail: amusura@zsem.hr (the address for correspondence);

Lidija Gamulin, ZBInvest, Croatia. behavioral economics and behavioral finance. These disciplines explain how human emotional and cognitive system shape economic reasoning and economic decision making. Relevant findings from these fields point to systematic biases in decision making. It seems that people are hardwired to make certain errors in judgment, to make irrational decisions under the influence of emotions, and to use heuristics to make judgments faster and efficiently but not necessarily correct ones. Taking that into account, our motivation behind this research is to explore the degree to which the investors are susceptible to different biases and heuristics. Also, we want to examine if there are sources of individual differences that predispose some investors to reason more rationally vs. heuristically. To determine the degree of heuristic reasoning, we will use hypothetical decision making situations taken from original papers (Hardman, 2009; Kahneman \& Tversky, 1979, 1992; Barber \& Odean, 2006; Pompian, 2006; Samuelson \& Zeckhauser, 1998; Thaler \& Johnson, 1990; Tversky \& Kahneman, 1974, 1983). Individual differences include different characteristics that describe investors' activities and experiences with capital markets.

\section{Background theory and hypothesis development}

The way people think, make decisions, and how they behave are central questions of two big social sciences economics and psychology. Despite their joint object of in- 
terest, economics and psychology developed two different perspectives on the question how people make decisions. These perspectives were based in different philosophical and methodological grounds. The field of judgment and decision making is one multidisciplinary scientific field that has been developing rapidly from the middle of $20^{\text {th }}$ century. On the one side, major contributions came from various economists, mathematicians, and statisticians, and on the other side, from many political and social scientists, philosophers, and psychologists. Two main pillars of judgment and decision making field are two models of decision making - normative and descriptive. Normative model revolves around the question how people should behave in order to be rational (as-if models). Norms that guide rational behavior come in a form of axioms and theoretical assumptions that are tested not empirically but in a realm of logical validity. Rational axioms are based on deductive logic and mathematical calculations (Baron, 2004). Some of these axioms include completeness (having well defined preferences), transitivity (preferences are consistent), continuity (any separation in preference can be maintained under a sufficiently small deviation in probabilities), and independence (preference is independent of the possibility of another outcome; Von Neumann \& Morgenstern, 1953). Rationality, thus, is defined by these axioms as referent points. Most of today's mainstream economic thought was founded on the assumptions of rational decision theory.

While normative models deal with optimally rational decisions, descriptive model explores how people make decisions in reality and which are their actual choices. Descriptive model accentuate the importance of psychological elements that influence decision making whereat human cognition excels as a major determinant of this process (Sternberg, 2004). After relevant psychological research in human cognition, axioms of rational decision making proved to be invalid because of disregarding cognitive capacities and lacking psychological realism. For example, research on framing and reversal of preferences proves that the way options are presented strongly influences the decision and thereby threatens most of von-Neumann's axioms (Tversky \& Kahneman, 1981). One of the founders in the decision making field, Herbert Simon, coined the term "bounded rationality" suggesting that people are not optimizers but satisficers - making decisions that are good enough and not optimal, based on one or several criteria, and needn't to be optimal with respect to some particular set of preferences. Due to limited cognitive capacity and very complex environment, people do best within the given framework of available mental energy and information (Simon, 1955). It often means that they cannot reach the optimal choice. Scientific field that arose from the fields of economics and psychology is a new scientific discipline called behavioral economics. Behavioral economics emerged in opposition to rational economic theory and in reaction to the notion that "cognitive and affective states" that cannot be directly observed must be out of the field of rational economics (Angner \& Loewenstein, 2006). More narrow definition of behavioral economics is the one that includes exploration of cognitive and emotional influences on economic decision making.

Major contribution of cognitive psychology to behavioral economics consists of the evidence about the mechanisms of human cognition. There are two modes of thinking inherent to all people - automatic and controlled reasoning or System 1 and System 2 thinking (Kahneman, 2011). Automatic reasoning makes out for most of people's daily thinking. Because of limited mental capacity and schematic structure of human knowledge, people use various mental shortcuts (heuristics) to make decisions under uncertainty while reducing the complexity of the task of assessing probabilities and predicting values to simpler judgmental operations. Most known heuristics are availability, representativeness, and anchoring (Tversky \& Kahneman, 1974; definitions of various heuristics can be found in the Appendix A). According to Kahneman (2011), behind these heuristics is automatic and low-effort System 1 thinking. It is responsible for making impressions, intuitions, intentions, and emotions. System 1, although fast, efficient, and correct most of the time, sometimes leads to systematic errors in judgment which can, again, lead to detrimental consequences.

Alternatively, Gigerenzer $(2005,2008)$ sees heuristics in very positive light - as adaptive mechanisms that, by employing bounded rationality, can lead to smart choices and better decisions. He has, following Simon's (1955) concept of bounded rationality, criticized normative models as being ecologically invalid since criteria for evaluating behavior as rational or irrational don't acknowledge the environment of the decision maker. Gigerenzer argues that in an environment with so much information and limited cognitive capacity for attending to them, heuristics based on one good reason can be as accurate as those based on many reasons. He even goes so far as to say that less is more, meaning that too much knowledge can lead to more errors and incorrect answers which is quite contra intuitive argument. Goldstein and Gigerenzer (2002) experimentally found that using heuristics that rely on having little knowledge can result in fast and correct judgments. It is also important to mention the field of naturalistic decision making that combines intuition as part of the System 1 thinking but based in knowledge and mastery of the environment in which an individual is making decisions (Klein, 2008).

The view of "flawless" intuitive skilled judgment that is made automatically and in complex environments is in contrast to more skeptical Kahneman's look at automatic thinking and expert judgment. Anyhow, both Kahneman and Klein came to an agreement that "the determination of whether intuitive judgments can be trusted requires an 
examination of the environment in which the judgment is made and of the opportunity that the judge has had to learn the regularities of that environment" (Kahneman \& Klein, 2009; p. 524). In other words, experts can learn patterns and rules, causes and effects of certain environment only if that environment provides good feedback, is predictable, and regular. For example, activities like playing chess or practicing to become a fire-fighter require that people practice and learn the rules in a stable and certain environment. Since investors are active in the environment that is irregular and unpredictable, we anticipate their irrationality. By irrationality, we consider departure from the behavior prescribed by rationality axioms and departure from the foundations of efficient market hypothesis (EMH) ${ }^{1}$. Additionally, we are interested in whether there are some personal characteristics that make investors more or less susceptible to commit errors in judgment.

In the context of exploring individual differences, some research indicates the existence of individual factors that contribute to more or less heuristic/biased reasoning of investors. Hon-Snir, Kudryavstev, \& Cohen (2012) found that more experienced investors are less affected by behavioral patterns in term of susceptibility to cognitive biases and heuristics. More experienced investors did not differ in the level of behavioral biases concerning their status as professional traders or non-professional traders. Experience also seems to be the determining factor for Anderson and Sunder (1995). Barber and Odean (2006) argue that professional investors are less prone to indulge in attention-driven purchases, and with more time and resources, professionals are able to continuously monitor a wider range of stocks. Working to improve human reasoning, there are many studies that put light on a relationship between statistical (methodological) education and better reasoning devoid of errors (Agnoli, 1991; Cheng, Holyoak, Nisbett, \& Oliver, 1986; Crandall \& Greenfield, 1986; Fong, Krantz, \& Nisbett, 1986; Nisbett, Fong, Lehman, \& Cheng, 1987; Nisbett, Krantz, Jepson, \& Kunda, 1983; Schaller, Asp, Rosell, \& Heim, 1996).

In present research, we will use a set of hypothetical decision making scenarios as a measure of heuristical/biased reasoning. Results on these scenarios will be correlated with

1 One of the cornerstones of modern financial theory, the theory that got even further from the reality is EMH (Mishkin \& Eakins, 2008). This theory, that got universally accepted, shares the same foundations as rational decision theory does - it states that the share prices reflect all the relevant information that is available to all rational investors on the market. Basic assumptions of EMH are that most of the investors are rational and they rationally evaluate financial products; if investors are not rational, they are not numerous and their transactions are annulated by the majority of rational investors. As such, EMH cannot explain the occurrence of market bubbles (when prices of financial products rise independently of fundamental values) a group of relevant individual variables. We hypothesize that investors, in general, are susceptible to heuristical/biased reasoning (Hypothesis 1). Led by this expectation, we assume that on all or majority of scenarios we will find the presence of particular heuristic or bias.

Furthermore, we expect that educational background in finance, professional experience with money, and years of experience within the market will significantly differentiate investors who are more and less susceptible to heuristics and biases (Hypothesis 2). Following the line of thought from previous research, we assume that investors with educational background in finance, more years of experience in investing, including frequency of trading as a measure of experience, and professional status or past experience with investing will be less susceptible to heuristical/biased reasoning.

\section{METHODOLOGY}

\section{Instrument}

The survey was created online using QuestionPro online survey software. It consisted of seven questions related to demographic characteristics and eight questions as indicators of certain heuristics and biases. In the Appendix A we listed all hypothetical situations used in original studies or adjusted for this survey. For each situation or scenario, we allocated a score of 0 or 1 depending on whether the response indicates the heuristic/bias or not ( 1 for heuristi$\mathrm{cal} /$ biased response). Although each of these scenarios represents a single item, the scores were summed to form a composite variable. By summing up the scores, we do not assume that these situations have a one-dimensional latent structure. However, there are indications that these scenarios have some degree of common variance (Toplak, West, \& Stanovich, 2011). All scenarios reflect some sort of financial decision making, usually gambling or investing.

\section{Participants and procedure}

Initial list of potential participants was made out of contacts available through Croatian Financial Market Association (ACI), client base of couple of brokers associations and personal contacts. The list included approximately 700 contacts. The final sample consisted of 139 valid surveys (20\% response rate), gathered using computerized survey (Appendix B). All potential participants were contacted by e-mail, encompassed by letter explaining the purpose of the study. The survey was anonymous and conducted during spring 2011. Participants were mostly male (80\%), with age between 31 and 40 (59\%) and educational background mostly in finance $(44 \%$; Table 1$)$. 
MUŠURA GABOR and GAMULIN, Investors' rationality, Review of Psychology, 2016, Vol. 23, No. 1-2, 15-25 International Journal of Croatian Psychological Association published by Naklada Slap

Table 1

Demographic variables, categories and valid frequencies

\begin{tabular}{|c|c|c|}
\hline Variable & Valid N & Valid \% \\
\hline \multicolumn{3}{|l|}{ Gender } \\
\hline Male & 110 & 80 \\
\hline Female & 28 & 20 \\
\hline \multicolumn{3}{|l|}{ Age } \\
\hline$<30$ & 15 & 11 \\
\hline $31-40$ & 81 & 59 \\
\hline $41-50$ & 28 & 20 \\
\hline$>51$ & 14 & 10 \\
\hline \multicolumn{3}{|l|}{ Education } \\
\hline More finance oriented & 60 & 44 \\
\hline More business oriented & 23 & 17 \\
\hline Other & 52 & 39 \\
\hline \multicolumn{3}{|l|}{ Professional investors status/experience } \\
\hline Yes (survey question 16, answers 1-7) & 70 & 55 \\
\hline No (survey question 16, answers 8-10) & 58 & 45 \\
\hline \multicolumn{3}{|l|}{ Years of investors experience } \\
\hline$<5$ (survey question 17, answers 2-3) & 65 & 47 \\
\hline$>5$ (survey question 17, answer 1) & 74 & 53 \\
\hline \multicolumn{3}{|l|}{ Frequency of investing } \\
\hline At least once a week & 35 & 26 \\
\hline At least once a month & 26 & 19 \\
\hline At least once in a three months & 29 & 22 \\
\hline At least once a year & 45 & 33 \\
\hline \multicolumn{3}{|l|}{ Number of stocks in portfolio } \\
\hline$<3$ & 27 & 20 \\
\hline $3-10$ & 67 & 49 \\
\hline$>10$ & 43 & 31 \\
\hline
\end{tabular}

\section{RESULTS}

At the beginning of our analysis, we started with descriptive statistics related to each scenario that served as a measure of heuristical/biased reasoning (Table 2). For five out of eight scenarios we have found statistically significant difference between the frequencies of responses in the direction of giving heuristical/biased response. Nevertheless, for two scenarios the direction of responses indicates that participants are by great majority giving unbiased responses (availability heuristic and house money effect).

Test of intercorrelations between decision scenarios revealed only one significant correlation coefficient between representativeness heuristic and loss aversion, $r=.29, p<$ .01. All other scenario scores are unrelated.

To test the assumption about the association between certain characteristics related to capital market activities and susceptibility to heuristics and biases, we conducted further correlation analyses. Since the scenarios were cate-
Table 2

Percentage of different scores and Chi-square test $(d f=1)$ for all decision scenarios

\begin{tabular}{|c|c|c|c|c|}
\hline \multirow{2}{*}{ Heuristics/Biases } & \multicolumn{2}{|c|}{$\begin{array}{l}\text { Heuristical/ } \\
\text { biased score }\end{array}$} & \multicolumn{2}{|c|}{ Goodness-of-fit test } \\
\hline & 0 & 1 & $\chi^{2}$ & $p$ \\
\hline Representativeness heuristic ${ }^{\text {a }}$ & 55 & 45 & 1.216 & .270 \\
\hline Loss aversion $1^{\text {a }}$ & 37 & 63 & 8.813 & .003 \\
\hline Loss aversion $2 \mathrm{~b}$ & 32 & 68 & 18.116 & .000 \\
\hline Mental accounting ${ }^{b}$ & 40 & 60 & 5.681 & .017 \\
\hline Underreaction ${ }^{b}$ & 14 & 86 & 72.464 & .000 \\
\hline Availability heuristic $^{b}$ & 92 & 7 & $100.899^{d}$ & .000 \\
\hline Stauts Q bias ${ }^{b}$ & 18 & 81 & 56.116 & .000 \\
\hline House money effect ${ }^{c}$ & 82 & 17 & $58.696^{d}$ & .000 \\
\hline
\end{tabular}

Note. Significant differences are shown in boldface.

${ }^{\mathrm{a}} N=139 .{ }^{\mathrm{b}} N=138 .{ }^{\mathrm{c}} N=116 .{ }^{\mathrm{d}}$ Responses that indicate that participants are by great majority giving unbiased responses.

gorical variables and in some cases there were small number of participants in certain response categories, we avoided regression analysis. There is one significant correlation between house money effect and years of investing, $r=.18$, $p<.01$. The more experience in investing participants had, the more susceptive to house money effect they were. All other correlations between years of investing experience and heuristics/biases were insignificant. No correlation was found between certain heuristics/biases and frequency of investing or number of stocks in portfolio.

Since two of our relevant questions, that were used as indicators of the level of participants' capital market activities, were categorical, we used chi-square analysis to test whether there is a difference in frequencies in number of investors who gave heuristical/biased responses across different categories of educational background and professional experience in investing (Table 3 ). There is a general tendency to give more heuristical/biased responses in the category of participants that have their education background in business, $M=4.9, S D=1.4$. On average, those with finance education give less heuristical/biased answers, $M=4.3, S D$ $=1.3$. This difference is statistically significant, $F(1,178)=$ $6.140, p<.05$. The significance levels indicate that in two scenarios (representativeness and mental accounting) we found statistically significant differences in average heuristical/biased result across different educational backgrounds.

With relation to professional experience in investing, we found statistically significant result in three scenarios (loss aversion, underreaction, and availability). There is a minor (insignificant) difference in tendency for participants without professional experience, $M=4.3, S D=1.2$, to exhibit less susceptiveness to heuristics and biases in terms of average of biased scores compared to those with experience, $M$ $=4.5, S D=1.3$. In three scenarios, we found different levels 
MUŠURA GABOR and GAMULIN, Investors' rationality, Review of Psychology, 2016, Vol. 23, No. 1-2, 15-25 International Journal of Croatian Psychological Association published by Naklada Slap

Table 3

Chi-square tests $(d f=2)$ for the frequency of investors who gave heuristical/biased answers across different educational backgrounds and professional experience in investing

\begin{tabular}{|c|c|c|c|c|c|c|c|c|}
\hline \multirow{2}{*}{ Heuristics/Biases } & \multicolumn{4}{|c|}{ Educational background } & \multicolumn{4}{|c|}{ Professional experience } \\
\hline & Finance & Business & $\chi^{2}$ & $p$ & Yes & No & $\chi^{2}$ & $p$ \\
\hline Representativeness heuristic & $35(56 \%)$ & $18(82 \%)$ & 4.791 & .039 & $43(57 \%)$ & $26(49 \%)$ & 0.856 & .355 \\
\hline Loss aversion 1 & $43(67 \%)$ & $18(82 \%)$ & 1.700 & .192 & $54(72 \%)$ & $32(60 \%)$ & 1.903 & .168 \\
\hline Loss aversion 2 & $46(72 \%)$ & $16(73 \%)$ & 0.006 & .939 & $58(77 \%)$ & $31(57 \%)$ & $\mathbf{5 . 8 2 7}$ & .016 \\
\hline Mental accounting & $33(52 \%)$ & $17(77 \%)$ & 4.171 & .041 & $44(59 \%)$ & $37(70 \%)$ & 1.660 & .198 \\
\hline Underreaction & $57(91 \%)$ & $18(82 \%)$ & 0.177 & .278 & $67(89 \%)$ & $37(70 \%)$ & 7.769 & .005 \\
\hline Availability heuristic & $3(5 \%)$ & $2(9 \%)$ & 0.580 & .466 & $3(4 \%)$ & $9(17 \%)$ & 6.096 & .014 \\
\hline Status Q bias & $50(80 \%)$ & $18(82 \%)$ & 0.061 & .804 & $61(81 \%)$ & $45(85 \%)$ & 0.278 & .598 \\
\hline House money fallacy & $9(14 \%)$ & $7(18 \%)$ & 0.191 & .662 & $13(17 \%)$ & $10(19 \%)$ & 0.066 & .797 \\
\hline
\end{tabular}

Note. Significant differences are shown in boldface.

of heuristical/biased reasoning between participants with and without professional experience in investing. It seems that the effect of professional experience in investing has no clear relationship with the tendency to give heuristical and biased answers.

\section{DISCUSSION AND CONCLUSIONS}

To test our first assumptions about the susceptiveness to various heuristics and biases, we analyzed overall tendency to give heuristical and biased responses. On five out of eight heuristics/biases, participants exhibited the existence of susceptibility to heuristics and biases. Only on two scenarios, the great majority of responses reside on the more rational side. Since the majority of scenarios revealed irrational tendencies, we can conclude that our first hypothesis is mostly confirmed. By now, it is well known that heuristics and biases help people decide and reason quickly. This tendency to irrationality in terms how economics defines it might be an indicator of pretentious assumptions that normative theory of rationality and EMH has put in front of a rational investor. Tendency to act not in accordance to assumptions of rational theory or EMH is one major and legitimate reason of market's volatility, unpredictability, and related phenomena like market bubbles, etc. Furthermore, since the market is quite unpredictable and uncertain environment that disables learning of its rules, our findings can be related to Kahneman and Klein's (2009) agreement on how experts learn. Of course, the results of this research cannot be used for generalization since the sample in this research is not representative nor the hypothetical situations can be equated with the real life decisions.

The absence of meaningful and significant correlations between the hypothetical scenarios used indicates that these situations might not have similar or latent construct/process behind them. This finding discouraged us from making an index of heuristical/biased reasoning. However, this finding reflects the fact that each one of these hypothetical decision making scenarios is a story for itself, helping define a particular phenomenon, and is very contextual. In the new discipline of behavioral economics, there is still no great model or theory that could explain latent processes that relate all these phenomena except the well-known theory of dual processes. In the future research, there is a need for developing an instrument that could serve as a valid measure of tendency for heuristical/biased reasoning.

Different categories of educational background and professional experience are somewhat correlated with the tendency of resisting some heuristics/biases. In the case of representativeness heuristic, availability heuristic and mental accounting, participants with educational background in finance gave more responses that are rational. It seems that educational background could have some effect on susceptibility to heuristical/biased reasoning.

Professional experience in investing, moreover, does not seem to have a rationalizing effect on investors in our sample as Anderson and Sunder (1995), Barber and Odean (2006), and Hon-Snir et al. (2012) found in their research. Experience, in term of years spent in investing activities, does not differentiate investors according to their level of susceptibility to heuristics and biases. It is advisable to further explore how these experiential influences shape individuals' rationality and the ability to resist automatic and contextual heuristics and biases. Anyhow, the finding about finance education that could lead to greater rationality is worth exploring. There is a line of research that is focused on the correlation between education in economics and tendency to be more rational, selfish, and less prone to cooperation (James, Soroka, \& Benjafield, 2001; Lanteri, 2008; Zhou, 2010). This line of research is mostly correlational in nature. There are some research that suggest that learning finance helps reduce some biases (Greenberg \& Shtudiner, 2016; Lahav, Rosenboim, \& Shavit, 2015; Shavit, Lahav, \& Rosenboim, 2016). Education in finance is more focused on quantitative 
knowledge, which could have more rationalizing impact on reasoning. Yet, individuals who are attracted to the field of finance could already be more rational. Nevertheless, since there are no correlations between the scenarios, it is hard to give any conclusion or assumption related to this finding.

Overall, it seems that educational background has a potential to be a relevant individual variable that might differentiate investors by their level of rationality. Thus, we only partially confirmed our second hypothesis. These findings may serve as a tool for deepening our understanding of the effects of education on susceptibility to automatically generated reasoning errors and be useful information for financial companies' managers. Additionally, these findings are aligned with descriptive decision making theories that help reveal real human behavior within its environment. It is necessary to note that the real effects of investors reasoning need to be examined within the markets or using computerized simulations that have higher levels of psychological realism. Since there are no consistent findings with regards to investors individual differences and reasoning, findings from this study may be indicative and suggest a path for further research. Additional advantage of this study is that it is conducted on real investors instead of a student sample as is used in most judgment and decision making research.

Limitations of this study include non-probabilistic and relatively small sample of investors. For further research, it is advisable to analyze closely the relationships between various individual characteristics on a larger and more representative sample of investors. Also, there is a research gap related to questioning latent processes or factors that can be responsible for susceptibility to different kinds of heuristics. For now, methodology used for exploring heuristics and biases is mostly based on hypothetical and thus idiosyncratic situations that show small or non-existing intercorrelations with other similar situations or heuristics.

\section{REFERENCES}

Agnoli, F. (1991). Development of judgmental heuristics \& logical reasoning: Training counteracts the representativeness heuristic. Cognitive Development, 6(1), 195217. doi:10.1016/0885-2014(91)90036-D

Anderson, M. J., \& Sunder, S. (1995). Professional traders as intuitive Bayesians. Organizational, Behavioral \& Human Decision Processes, 64, 185-202. doi:10.1006/ obhd.1995.1099.

Angner, E., \& Loewenstein, G. (2007). Behavioral Economics. In: D. Gabbay, P. Thagard \& J. Woods (Eds.), Handbook of the philosophy of science (pp. 641-690). Amsterdam: Elsevier.

Barber, B. M., \& Odean, T. (2006). All that Glitters: The Effect of Attention \& News on the Buying Behavior of Individual \& Institutional Investors. The Review of Financial Studies, 21, 785-818. doi:10.1093/rfs/hhm079
Baron, J. (2004). Normative models of judgment \& decision making. In: D. J. Koehler \& N. Harvey (Eds.), Blackwell handbook of judgment \& decision making (pp. 19-36). London: Blackwell. doi:10.1002/9780470752937.ch2

Browning, G. L., Halcli, A., \& Webster, F. (1999). Understanding contemporary society: Theories of the present. Thousand Oaks: SAGE. doi:10.4135/9781446218310

Cheng, P. W., Holyoak, K. J., Nisbett, R. E., \& Oliver, L. M. (1986). Pragmatic versus syntactic approaches to training deductive reasoning. Cognitive Psychology, 18, 293-328. doi:10.1016/0010-0285(86)90002-2

Crandall, C. S., \& Greenfield, B. S. (1986). Understanding the conjunction fallacy: A conjunction of effects? Social Cognition, 4, 408-419. doi:10.1521/soco.1986.4.4.408

Fong, G. T., Krantz, D. H., \& Nisbett, R. E. (1985). The effects of statistical training on thinking about everyday problems. Cognitive Psychology, 18, 253-292. doi:10.1016/0010-0285(86)90001-0

Gigerenzer, G. (2005). I think, therefore I err. Social Research, 72(1), 1-24.

Gigerenzer, G. (2008). Snaga intuicije: Inteligencija nesvjesnog [Gut feelings: The intelligence of the unconscious]. Zagreb: Algoritam.

Goldstein, D. G., \& Gigerenzer, G. (2002). Models of ecological rationality: The recognition heuristic. Psychological Review, 109, 75-90. doi:10.1037//0033295x.109.1.75

Greenberg, D., \& Shtudiner, Z. (2016). Can financial education extend the border of bounded rationality? Modern Economy, 7, 103-108. doi:10.2139/ssrn.2708835

Hardman, D. (2009). Judgement \& decision making. Oxford: BPS-Blackwell.

Hon-Snir, S., Kudryavstev, A., \& Cohen, G. (2012). Stock market investors: Who is more rational, \& who relies on intuition. International Journal of Economics \& Finance, 4, 56-72. doi:10.5539/ijef.v4n5p56

James, T., Soroka, L., \& Benjafield, J. G. (2001). Are economists rational or just different. Social Behavior \& Personality, 29(4), 359-364. doi:10.2224/ sbp.2001.29.4.359

Kahneman, D. (2011). Thinking fast and slow. New York: Farrar, Strauss and Giroux.

Kahneman, D., \& Klein, G. (2009). Conditions for intuitive expertise: A failure to disagree. American Psychologist, 64, 515-526. doi:10.1037/a0016755

Kahneman, D., \& Tversky, A. (1979). Prospect theory: An analysis of decisions under risk. Econometrica, 47(2), 263-291. doi:10.2307/1914185

Kahneman, D., \& Tversky, A. (1992). Advances in prospect theory: Cumulative representation of uncertainty. Journal of Risk \& Uncertainty, 5, 297-323. doi:10.1007/ bf00122574 
Klein, G. (2008). Naturalistic decision making. Human Factors, 50(3), 456-460. doi:10.1518/001872008x288385

Lahav, E., Rosenboim, M., \& Shavit, T. (2015). Financial literacy's effect on elicited subjective discount rate. Economics Bulletin, 35(2), 1360-1368.

Lanteri, A. (2008). (Why) selfish people self-select in economics? Erasmus Journal of Philosophy \& Economics, $1(1), 1-23$.

Mishkin, F. S., \& Eakins, S. G. (2008). Financial markets \& institutions. New York: Nova Publishers.

Nisbett, R. E., Fong, G. T., Lehman, D. R., \& Cheng, P. W. (1987). Teaching reasoning. Science, 238, 625-631.

Nisbett, R. E., Krantz, D. H., Jepson, C., \& Kunda, Z. (1983). The use of statistical heuristics in everyday life inductive reasoning, Psychological Review, 90, 339363. doi: $10.1126 /$ science. 3672116

Pompian, M. (2006). Behavioral finance \& wealth management - How to build optimal portfolios that account for investor biases. New Jersey: Wiley.

Samuelson, W., \& Zeckhauser, R. (1988). Status Quo Bias in Decision Making. Journal of Risk \& Uncertainty, 1, 7-59. doi:0.1007/bf00055564

Schaller, M., Asp, C. H., Rosell, M. C., \& Heim, S. J. (1996). Training in statistical reasoning inhibits the formation of erroneous group stereotypes. Personality \& Social Psychology Bulletin, 22, 829-844. doi:10.1177/0146167296228006

Shavit, T., Lahav, E., \& Rosenboim, M. (2016). Don't fear risk, learn about it: How familiarity reduces perceived risk. Applied Economics Letters, 23(15), 1069-1072. do i:10.1080/13504851.2015.1133892

Shefrin, H., \& Statman, M. (1985). The disposition to sell winners too early and ridelosers too long: Theory and evidence. The Journal of Finance, 40(3), 777-790. doi:10.1111/j.1540-6261.1985.tb05002.x
Simon, H. A. (1955). A behavioral model of rational choice. The Quarterly Journal of Economics, 69(1), 99-118. doi: $10.2307 / 1884852$

Slovic, P., Fischhoff, B., \& Lichtenstein, S. (1979). Rating the Risks. Environment: Science \& Policy for Sustainable Development, 21, 14-20. doi:10.1080/00139157.1 979.9933091

Sternberg, R. (2004). Kognitivna psihologija [Cognitive psychology]. Jastrebarsko: Naklada Slap.

Thaler, R. H. (1999). Mental accounting matters. Journal of Behavioral Decision Making, 12, 183-206. doi:10.1002/ (SICI)1099-0771(199909)12:3 < 183::AID-BDM318> 3.0.CO;2-F

Thaler, R. H., \& Johnson, E. J. (1990). Gambling with the House Money \& Trying to Break Even: The Effects of Prior Outcomes on Risky Choice. Management Science, 36(6), 643-660. doi:10.1287/mnsc.36.6.643

Toplak, M. E., West, R. F., and Stanovich, K. E. (2010). The Cognitive Reflection Test as a predictor of performance on heuristics-and-biases tasks. Memory and Cognition, 39, 1275-1289. doi:10.3758/s13421-011-0104-1

Tversky, A., \& Kahneman, D. (1974). Judgment under uncertainty: Heuristics \& biases. Science, 185(4157), 1124-1131. doi:10.1126/science.185.4157.1124

Tversky, A., \& Kahneman, D. (1981). The framing of decisions \& the psychology of choice. Science, 211(4481), 453-458. doi:10.1126/science.7455683

Tversky, A., \& Kahneman, D. (1983). Extensional versus Intuitive Reasoning: The Conjunction Fallacy in Probability Judgment. Psychological Review, 90, 293-315. doi:10.1037/0033-295x.90.4.293

Von Neumann, J., \& Morgenstern, O. (1953). Theory of games \& economic behaviour. Princeton: Princeton University Press. doi:10.2307/2550081

Zhou, Z. (2010). Impact of Academic Experience in Economics on Risk Preferences and Rationality: An Empirical Investigation. Economics Student Scholarship, 6. Retrieved from http://scholar.oxy.edu/econ_student/6/ 


\section{APPENDIX A}

Hypothetical decision situations indicating various heuristics and biases

\begin{tabular}{|c|c|c|c|}
\hline $\begin{array}{l}\text { Cognitive heuristic } \\
\text { / bias }\end{array}$ & Definition & $\begin{array}{l}\text { Hypothetical situation (Italicized answers are indices of } \\
\text { heuristical or biased reasoning) }\end{array}$ & Original study \\
\hline $\begin{array}{l}\text { Representativeness } \\
\text { heuristic }\end{array}$ & $\begin{array}{l}\text { Probabilities are evaluated by the } \\
\text { degree to which A is representative of } \\
\text { B, that is, by the degree to which A } \\
\text { resembles B (Tversky \& Kahneman, } \\
\text { 1983) }\end{array}$ & $\begin{array}{l}\text { Assume that during five coin tosses, every time you get a } \\
\text { "head". If you had to bet } 1,000 \mathrm{kn} \text { on the next throw, what } \\
\text { would you choose? } \\
\text { "Head" ( } 1 \text { point) } \\
\text { "Tail" (1 point) } \\
\text { I have no preference ( } 0 \text { points) }\end{array}$ & $\begin{array}{l}\text { Tversky \& Kahneman, 1974, } \\
1983\end{array}$ \\
\hline Loss aversion (1) & $\begin{array}{l}\text { Preference where an individual is loss } \\
\text { averse if she or he dislikes symmetric } \\
50-50 \text { bets and, moreover, the aversive- } \\
\text { ness to such bets increases with the } \\
\text { absolute size of the stakes (Kahneman } \\
\text { \& Tversky, 1979) }\end{array}$ & $\begin{array}{l}\text { Choose one of the two options offered: } \\
\text { Sure loss of } 6,000 \mathrm{kn} \text { ( } 0 \text { points) } \\
\text { Having } 75 \% \text { chance to lose } 10,000 \mathrm{kn} \text { and } 25 \% \text { to lose } \\
\text { nothing ( } 1 \text { point) }\end{array}$ & $\begin{array}{l}\text { Adapted from various } \\
\text { studies. Similar situations } \\
\text { can be found in Hardman } \\
\text { (2009), Pompian (2006), and } \\
\text { Kahneman \& Tversky (1979, } \\
\text { 1992). }\end{array}$ \\
\hline $\begin{array}{l}\text { Mental accounting } \\
\text { (disposition effect) }\end{array}$ & & $\begin{array}{l}\text { Imagine if you bought a stock A of value } 20,000 \mathrm{kn} \text { and a } \\
\text { stock B of the same value. Soon the stock A's value in- } \\
\text { creases by } 10 \% \text {, while the value of a stock B falls by } 10 \% \text {. } \\
\text { You need cash urgently, which stock will you sell? } \\
\text { A ( } 1 \text { point) } \\
\text { B ( } 0 \text { points) }\end{array}$ & \\
\hline $\begin{array}{l}\text { Underreaction } \\
\text { (conservatism) }\end{array}$ & $\begin{array}{l}\text { Bias when limited attention leads to } \\
\text { underreaction to the absence of news, } \\
\text { which, by definition, is less salient and } \\
\text { vivid than the events covered by news } \\
\text { stories (Slovic, Fischhoff, \& Lichten- } \\
\text { stein, 1979). }\end{array}$ & $\begin{array}{l}\text { If you read the news that could have negative implica- } \\
\text { tions on the price of your stock, how fast would you have } \\
\text { reacted to this information? } \\
\text { I usually wait to see how the market will interpret the im- } \\
\text { portance of the news, and only after that I'll make decision } \\
\text { (1 point) } \\
\text { Sometimes I wait for the markets reaction, and sometimes I } \\
\text { react immediately ( } 1 \text { point) } \\
\text { I always react immediately (as soon as I find out the news) } \\
\text { ( } 0 \text { points) }\end{array}$ & Pompian, 2006 \\
\hline $\begin{array}{l}\text { Availability } \\
\text { heuristic }\end{array}$ & $\begin{array}{l}\text { Mental shortcut by which people } \\
\text { assess the frequency of a class or the } \\
\text { probability of an event by the ease with } \\
\text { which instances or occurrences can be } \\
\text { brought to mind (Tversky \& Kahne- } \\
\text { man, 1983) }\end{array}$ & $\begin{array}{l}\text { Suppose you are planning to purchase stocks of the } \\
\text { pharmaceutical company A. A friend sends you a report of } \\
\text { the company, the investment story sounds good, you plan } \\
\text { to buy its stocks. Just before your transaction, a financial } \\
\text { source announces that another pharmaceutical company B } \\
\text { just announced excellent financial results and that the share } \\
\text { price jumped } 10 \% \text { in one day with high volume. You will } \\
\text { react as follows: } \\
\text { Information about the company B will increase my belief } \\
\text { in the pharmaceutical sector as a good Investment and I } \\
\text { will continue to purchase stocks of Company A (0 points) } \\
\text { I'll wait a bit and look for company report for Company B } \\
\text { before proceeding to purchasing of stocks of company A } \\
\text { ( } 0 \text { points) } \\
\text { I prefer to buy shares of company B because it seems that } \\
\text { she is currently a hot stock, and therefore I want to be "in" } \\
\text { (1 point) }\end{array}$ & Barber \& Odean, 2006 \\
\hline
\end{tabular}


MUŠURA GABOR and GAMULIN, Investors' rationality, Review of Psychology, 2016, Vol. 23, No. 1-2, 15-25

International Journal of Croatian Psychological Association published by Naklada Slap

\begin{tabular}{|c|c|c|c|}
\hline \multirow[t]{5}{*}{ Status quo } & \multirow[t]{5}{*}{$\begin{array}{l}\text { Tendency to maintain one's current } \\
\text { or previous decision (Samuelson \& } \\
\text { Zeckhauser, 1998) }\end{array}$} & $\begin{array}{l}\text { You dedicatedly follow events in the financial markets, but } \\
\text { until recently you didn't have funds for investment. Now } \\
\text { you inherited a large sum of money. Considerable part } \\
\text { of the portfolio is invested in moderately risky portfolio. } \\
\text { Considering four different portfolios, in which one would } \\
\text { you invest? }\end{array}$ & \multirow[t]{5}{*}{$\begin{array}{l}\text { Samuelson \& Zeckhauser, } \\
1998\end{array}$} \\
\hline & & Invest in a moderately risky stock portfolio (1 point) & \\
\hline & & Invest in a risky stock portfolio ( 0 points) & \\
\hline & & $\begin{array}{l}\text { Invest in treasury bills (during the year, they will yield } 4 \% \text { ) } \\
(0 \text { points) }\end{array}$ & \\
\hline & & $\begin{array}{l}\text { Invest in bonds (during the year, they will yield } 6 \%)(0 \\
\text { points) }\end{array}$ & \\
\hline \multirow[t]{7}{*}{ House money } & \multirow{7}{*}{$\begin{array}{l}\text { Tendency to make decisions depend- } \\
\text { ant on the prior gain or loss; includes } \\
\text { greater tendency to gamble with re- } \\
\text { cently won money (Thaler \& Johnson, } \\
\text { 1990) }\end{array}$} & $\begin{array}{l}\text { (1) You have just received an unexpected 3,000 kn. Choose } \\
\text { one of the two options offered: }\end{array}$ & \multirow[t]{7}{*}{ Thaler \& Johnson, 1990} \\
\hline & & $\begin{array}{l}50 \% \text { chance to earn } 900 \mathrm{kn} \text { and a } 50 \% \text { chance to lose } 900 \\
\mathrm{kn}\end{array}$ & \\
\hline & & I do not want further gains or losses & \\
\hline & & $\begin{array}{l}\text { (2) You've just lost 3,000 kn. Choose one of the two op- } \\
\text { tions offered: }\end{array}$ & \\
\hline & & $\begin{array}{l}50 \% \text { chance to earn } 900 \mathrm{kn} \text { and a } 50 \% \text { chance to lose } 900 \\
\mathrm{kn}\end{array}$ & \\
\hline & & I do not want further gains or losses & \\
\hline & & $\begin{array}{l}\text { (If participant first gave response " } a \text { " than " } b \text { ", the score } \\
\text { was } 1 \text {, otherwise, 0) }\end{array}$ & \\
\hline
\end{tabular}




\section{APPENDIX B}

Questionnaire

Please take your time and fill-out this survey to the best of your ability. Read carefully the descriptions of hypothetical situations and mark (one) your answer. Your answers will be completely anonymous. All survey results will be used in scientific purposes. Thank you for your time and participation!

Assume that during five coin tosses, every time you get a "head." If you had to bet kn 1,000 on the next throw, what would you choose?
a. "Head"
b. "Tail"
c. I have no preference

Imagine if you bought a stock A of value is $20,000 \mathrm{kn}$ and a stock B of the same value. Soon the stock $\mathrm{A}^{\prime} \mathrm{s}$ value increases by $10 \%$, while the value of a stock B falls by $10 \%$. You need cash urgently, which stock will you sell?
a. A
b. B

If you read the news that could have negative implications on the price of your stock, how fast would you react to this information?

a. I usually wait to see how the market will interpret the importance of the news, and only after that I make decision

b. Sometimes I wait for market reaction, and sometimes I react immediately

c I always react immediately (as soon as I find out the news)

Suppose you are planning to purchase stocks of the pharmaceutical company A. A friend sends you a report of the company, the investment story sounds good, you plan to buy its stocks. Just before transaction, a financial website announces that another pharmaceutical company B just announced excellent financial results and that the share price jumped 10\% in one day with high volume. You will react as follows:

a. Information about the company B will increase my belief in the pharmaceutical sector as a good investment and I will continue to purchase stocks of Company A

b. I'll wait a bit and look for company report for Company B before proceeding to purchasing of stocks of company A

c. I prefer to buy shares of company B because it seems that she is currently a hot stock, and therefore I want to be "in"

You dedicatedly follow events in the financial markets, but until recently you did not have the funds for investment. Now you inherited a large sum of money. Considering four different portfolios, in which to invest?
a. invest in a moderately risky stock portfolio
b. invest in a risky stock portfolio
c. invest in treasury bills (during the year, they will yield 4\%)
d. invest in bonds (during the year, they will yield 6\%)

You have just received an unexpected kn 3000. Choose one of the two options offered:

a. $50 \%$ chance to earn $\mathrm{kn} 900$ and a 50\% chance to lose kn 900

b. I do not want further gains or losses

You've just lost kn 3000. Choose one of the two options offered:

a. $50 \%$ chance to earn $\mathrm{kn} 900$ and a 50\% chance to lose kn 900

b. I do not want further gains or losses

You've just lost kn 3000. Choose one of the two options offered:

a. $33 \%$ chance to earn $\mathrm{kn} 3000$ and $67 \%$ to earn kn 0

b. safe earning of $\mathrm{kn} 1000$ 


\section{DEMOGRAPHICS}

Your gender:
a. female
b. male

Age group you belong to:

less than 30 years
a. 31-40 years
b. 41-50 years
c. $51-60$ years
d. over 60 years

Your education:
a. related to finance
b. related to business
c. other

Professionally you are (or have been) in contact with the financial markets through:

a. employment in a financial institution as a broker

b. employment in a financial institution as a financial analyst

c. employment in a financial institution as a portfolio / fund manager

d. employment in a financial institutions as a board member

e. employment in a financial institutions as an investment advisor to clients Private Banking / Wealth Management

f. employment in the central bank, the CDA, the ZSE

g. employment in the treasury of a company

h. media coverage of financial markets

i. so far I have never had professional contacts with financial markets

j. something else
How long do you invest in stocks/trade (or other financial instruments, such as bonds or financial derivatives) on your own account?
a. more than 5 years
b. 1-5 years
c. less than 1 year
d. I do not invest / trade

How often do you invest in stocks/trade stocks (or other financial instruments, such as bonds or financial derivatives) on your own account?
a. at least one day
b. at least once a week
c. at least once a month
d. at least once a quarter
e. at least once a year

How many stocks (or other financial instruments, such as bonds or financial derivatives) are there in your portfolio?
a. less than 3
b. from 3-10
c. more than 10 
